\title{
The Fiscal Problems of Small Business in Albania
}

MSc. Edvin Xhango

\begin{abstract}
The aim of this study is the analysis of the fiscal law framework focused in the small businesses in Albania. The methodology used is a systematic literature review based mainly on Albanian legislation. Based on the Albanian fiscal legislation, classification of businesses it was done based on the sales that are realized. For over twenty - five years, taxes on small business often have changed, but the base of the manner for calculation of the tax is not change, it is relating with the turnover that is realize during one year. The study reached some conclusions. Thus, a) the review of groups that are included on the revision of the VAT and b) the review of profit tax small business.
\end{abstract}

Keywords: small business, small business tax, turnover

JEL Classifications: M, H, K

\section{Introduction}

Before talking about the reasons that push us to discuss the problems of small business it is important to show at the beginning what are the elements that qualify as a small business entity in Albania.

In fact, there are different classifications but what is observe is that the definition is similar to that in Europe, only the size and performance of the entity change. The difference consists first in the number of employees, which is the main criterion used in both definitions and second the criterion of the turnover.

Small and medium enterprises make up the most important economy in Albania. They constitute $94.5 \%$ of the total number of businesses and employed to $77.4 \%$ of individuals who are busy with work (INSTAT, 2009). These statistics show the importance of small business entities for the economy of Albania. Unfortunately, the importance of small businesses was not reflected in the economic legislation.

Albanian businesses for tax purposes are classified in fourth categories:

The first category realizes annual turnover businesses (annual revenues) up to 2 million (business ambulant)

The second category of businesses that realize turnover (annual income) load of 2 to 5 million (excluding VAT small business)

The third category of businesses that realize turnover (annual income) from 5 to 8 million (VAT small business)

The fourth category are businesses that realize an annual turnover over 8 million (big business) 
Figure 1
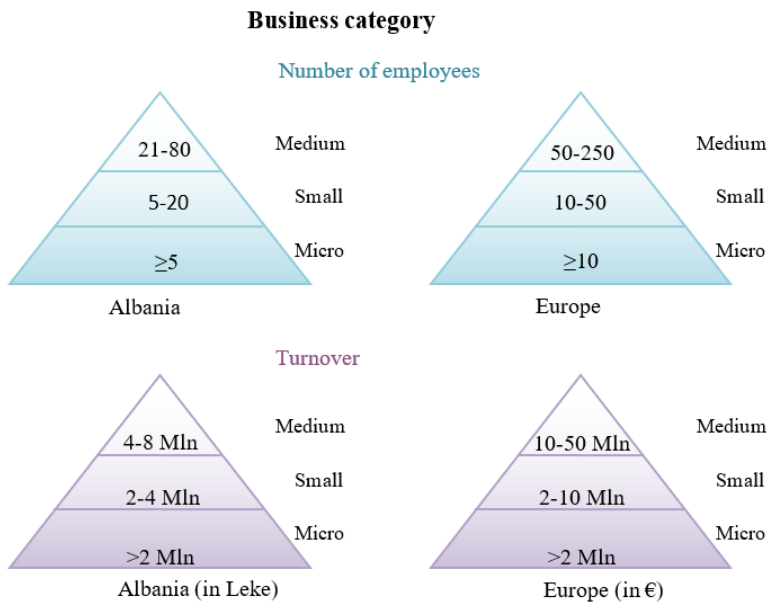

Source: INSTAT (2009)

The main reason that small business is select to study issues related to fiscal legislation are the fact that:

Small business contributes to increasing employment.

Small business mainly uses national resources.

Small business is the main contributor of the social insurance scheme and health care system

Small business is the main contributor to the budgets of local budget

Below are some data that compare budget revenues by type of business

Figure 2

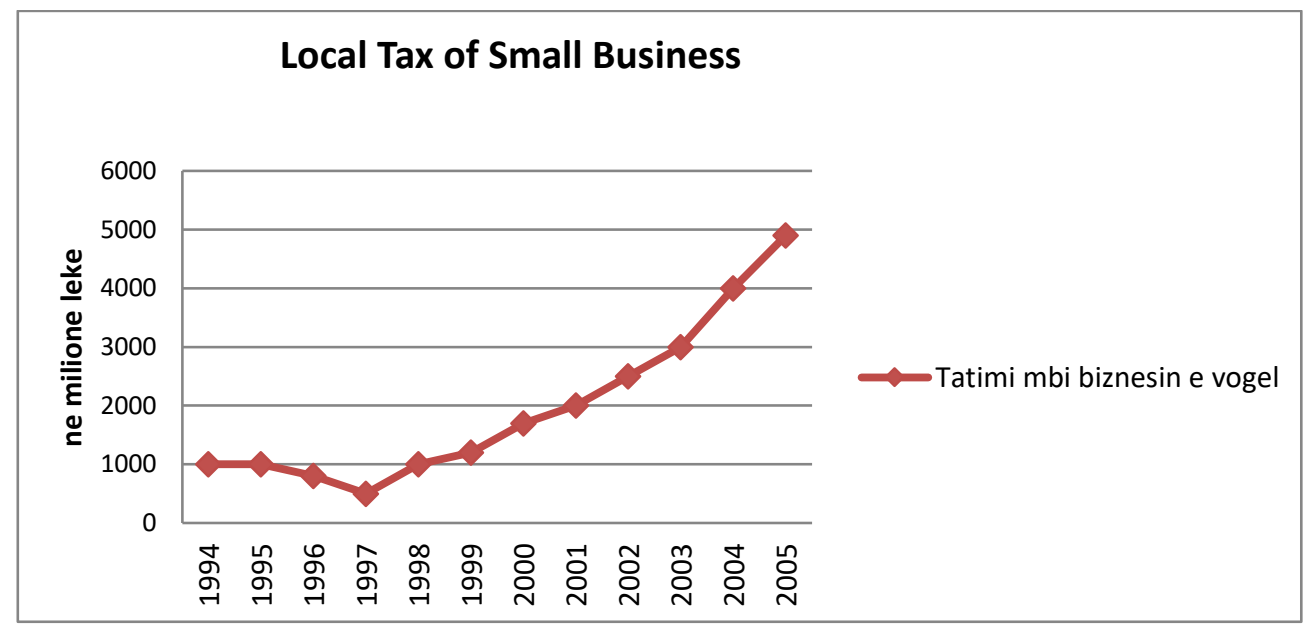

Source: General Directory of Taxes (2008) 
The performance of this tax is more than satisfactory (if we refer to the chart), it has recorded an average annual growth of more than 24 percent since 1994. As noted, the first years of application of this tax have been difficult, not only from the fact that the volume of the work of small businesses was modest, but also for the culture of society paying taxes low. The years 1996 - 1997 marked regression in the implementation of this tax as revenue fell 14 and 49 percent respectively during these years. It was because of unsuccessful businesses and due to non-functioning state. In 1998 the tax revenue recovered, marking an increase of over $136 \%$. During the period $1999-2004$, the average annual increase of this tax has been over 28. 5 percent. While local tax on small business for 2008 reaching 1.8 billion

Table 1

The income generated over the years by three groups of subjects (in mil All)

\begin{tabular}{|l|l|l|l|l|l|l|l|l|l|l|l|l|}
\hline No. & Tipe & 2003 & 2004 & $04 / 05$ & 2005 & $05 / 04$ & 2006 & $06 / 05$ & 2007 & $07 / 06$ & 2008 & $08 / 07$ \\
\hline 1 & SB & 8. & 9. & $18 \%$ & 11. & 12. & 12. & $10 \%$ & 12. & 3. & 15. & 21. \\
& & 322 & 835 & & 04 & $2 \%$ & 147 & & 602 & $70 \%$ & 303 & $40 \%$ \\
\hline 2 & MB & 1.78 & 2. & $\begin{array}{l}16 . \\
071\end{array}$ & $\begin{array}{l}2 . \\
3 \%\end{array}$ & -0 & 2. & 9. & 2. & $3 \%$ & 3. & \\
& & & 084 & & 275 & $10 \%$ & 344 & & 118 & $33 \%$ \\
\hline 3 & BB & 142 & 252 & $\begin{array}{l}77 . \\
4 \%\end{array}$ & 242 & -0 & 217 & - & 233 & $\begin{array}{l}7 . \\
30 \%\end{array}$ & 394 & $69 \%$ \\
\hline 4 & Others & 59 & 206 & $349 \%$ & 318 & $54 \%$ & 394 & $23 \%$ & 456 & $\begin{array}{l}15 \\
7 \%\end{array}$ & 457 & \\
& & & & & & & & & & $7 \%$ \\
\hline
\end{tabular}

Source: Newsletter of Directorate General of Tax, 2008

During 2008, we have an increase of 21. 4 \% for Small Business, $33 \%$ for Big Business and $69 \%$ for VIP business. We can clearly see a significant increase in small business income.

\section{Literature review}

In the high-income economies, MSMEs are not only denser in the business structure, but also employ a higher percentage of the workforce. In half of the high-income economies covered, formal MSMEs employed at least 45 percent of the workforce, compared to only 27 percent in low-income economies (Kushnir, Mirmulstein and Ramalho, 2007).

Competition from the informal sector and corruption among government officials also pose significant challenges for firms. Objective measures of the size of the informal sector, barriers to entry into and exit from the formal market, and the existence of informal payments shed light on the importance of these obstacles to the existence of MSMEs (Kushnir et al, 2007).

Nevertheless, small business is disproportionately vulnerable to tight regulation, high taxation, bureaucratic burdens, and even corruption (e. g. Aidis, 2003), (Bartlet et al. , 2005), (Borozan et al. , 2005)). It is thus believed to be prone to leaking into the shadow economy. On the other hand, the increased internationalization of the economy and increasing competitive market pressures have promoted flexibility and innovativeness, but - along with the growth in small business - have deepened income inequalities. In such harsher competitive global circumstances, people have been forced to seek alternative sources of income. This has further encouraged and increased small business activities, but at the same time many of the new businesses have been started up in the shadow economy. High taxes and high bureaucratic transaction costs have increased this shift into the shadow economy.

European Commission (2004) and OECD (2002) underline a direct causality between small businesses, as proxied by the number of self-employed persons, and the shadow economy. It is assumed that small businesses, being flexible and easier to conceal from the authorities, have more scope to work undetected in the shadow economy. Furthermore, higher taxes and other regulations increase the incentives to hide

Taxes and social security contributions add to the cost of labour in the official economy and hence are key factors driving the growth of the shadow economy (Shende, 2002). The bigger the difference between the total cost of labour in the official economy and the after-tax earnings from work, the greater the incentive for employers and employees to avoid this difference and participate in the shadow economy. The difference can be very large; in Germany and Austria, for example, the tax and social security payments by firms and their workers amount to the wages that workers effectively earn. Since 
the difference depends broadly on the social security system and the tax regime, these are key determinants of the shadow economy. Several studies have found strong evidence that the tax regime influences the shadow economy.

\section{How has evolved tax legislation on small businesses and the problems that are encountered}

In 1993 the law "On taxes on small businesses" was approved which divided into two groups all the businesses in Albania; in subjects with a turnover of up to two million and, in entities with a turnover of up to five million. For small businesses with a turnover of up to two million the way of calculating tax liabilities has not been changed. They all the time have had a fixed fee regardless of the realized turnover, type of activity or location.

Small business entities with a turnover of over two million ALL have been subject to constant legal changes regarding fiscal obligations. According to this law, small businesses with annual turnover of 2- 5 million ALL, had a taxation depending on the amount of revenues and performing subject activity.

With the changes made in the law of 1998 the tax rate was determined on $4 \%$ of the sale turnover. In the case of fixed tax rate the location and type of activity are not taken into account. With the changes of 1998, the tax was calculated on the basis of the sales turnover, and depended not on other expenses or even on the markup which is different for different businesses. For example the same markup used in a cafe or restaurant is not the same as the markup in a market that sells food. This fact was taken into consideration in the law of 1993, where the tax rate was based on the type of activity. Nevertheless, both cases have not taken into account the location, a fact that disregards specific areas with extreme poverty.

In 2002, taxes for small businesses is only subordinated to the city and the industry in which the entity operates, being only a fixed amount similar to the manner of determining the obligations of businesses up to two million.

By 2006, the way of small business tax has not undergone significant changes. The changes made in fiscal 2006 scheme envisage a mix of the previous system, fixed fee that depends on the location and type of activity adding the tax on sales realized by the entity. In this way small businesses become subject to two separate taxes for the same thing.

This means that the tax burden for the service business was:

$\mathrm{TSB}+\mathrm{TS}($ tax of sale $)=35000+0.15 * 2.000 .000=65.000 \mathrm{ALL}$ or $3 \%$ of the proceeds of the unit

If we analyze the trade sector retail:

TBV + TS $($ tax of sale $)=60.000+0.015 * 8.000 .000=180.000$ or $2.25 \%$

This means that the bigger the turnover the smaller the tax level as relative value. In this case, we are dealing with a favour (in relative value) to the business with greater turnover, (compared with the scheme that defined the previous law in which all businesses with a turnover of 2-8 million had a tax of $4 \%$ over the sales turnover.

\section{Fiscal reform nowadays}

After 2009, it has become a comprehensive reform on fiscal obligations, thus:

The concept of the personal income tax was introduced, which is identical to the concept of income tax in the case of the big business - the calculated profit and the way of payment of the tax profit. This because: first the profit is calculated as the difference between the revenues with known expenses, which are defined as for the big business, and second (the paided amount of the small business tax (SBT) is deducted from the personal income tax (PIT), like in the case of the big business the prepaid income tax was deducted.

Medium-sized businesses must be register in the VAT scheme, which enhances the fiscal burden for these businesses perhaps at the levels of large business. This because municipal taxes approximate the minimal value of the income tax. However, this action reduces the possibility for tax evasion, as the companies become more concerned to record the supplies with tax bills. Also, become more responsive to sell items associated with tax bill.

Quite significant was the reduction of contributions for compulsory social insurance and health care for employees which is a facility for the business 
At the beginning except financial costs (these changes also were associated with technical difficulties:

It was unclear relationship of the businesses with the tax administration. That means the process of tax evaluation will be carry out by the local tax administration or the central government.

It was unclear if VAT would be evaluating and how would be evaluated the available inventory and other tangible assets that were in the entity at the 1 January 2010.

In 2015, there were other significant changes in the fiscal obligations for small business. Thus:

All fiscal obligations for businesses with a turnover of up to five million were taken away. This facilitated the activity of these businesses by the fiscal burden, but the difference between small- and micro-sized business became greater.

The small business income tax was lowered.

These changes are important because facilitate the businesses with modest turnover. The shortcoming of these changes is that the not fair competition increases and distorts the market because the business tax burden for a slightly larger turnover is quite heavy. Therefore, businesses with a turnover exceeding five million All are subject to VAT and income tax, compared to their competitors who have turnover below five million All, but fiscal burden for them is zero. This action will promote the subjects tend to be business entities of up to five million All.

\section{Free Professions}

Free professions are well-qualified individuals who provide qualified services as legal, medical, financial, etc. Until 2006, the providers have to implement the same legal definitions as other small businesses. In 2006, it was determined that these businesses will be subjected to VAT for services provided regardless of realized turnover. In 2015 , the reference salary for these professionals was defined in the schema for payments of social and health security. This reference salary was around three times greater than the salary for other self-employed.

\section{Conclusions and recommendations}

\section{Conclusion}

The transition of small business to the VAT scheme is right, because it leads to the formalization of the sector of small businesses. Until now small businesses were more interested to find cheaper products and services although they can take without a receipt. So the wholesalers become a small discount and no bill was given. Passing on the VAT scheme the entrepreneurs of the small business increasingly will seek to obtain the bill then would go to the formalization of the economy.

The fiscal burden for businesses should be reviewed as who benefits from the services should contribute to the services he received.

The fiscal load for freelancers should be reviewed because it is very discouraging when this burden is equal to this for the medium-sized businesses.

The increased of the recognized expenses will increase the degree of formality, because in this way businesses will be interested to take the bill from entities that provide them the services. Some of the various expenses of the business are not recognize for tax purposes by the law, then called not recognized expenses. For the sake of a price small businesses are more interested in the offer than to get the bill, which it leads to tax evasion.

\section{Recommendations}

Involved into the scheme of VAT that the business turnover of 2-5 All. This order for these businesses to be interested to receive the tax bill.

Exemption from VAT of freelancers. As noted in literature review, due to tax evasion are high, as is the case for VAT. Also this is a business that can be developed at home makes it difficult to identify him. 
Recognition by the tax authorities of all expenditures with proper documentation. So that businesses will carry the costs will be loaded with payment of tax. Businesses are also interested to receive receipts for these expenses and the state to obtain income from the company that will conduct the sale

Inclusion of the business up to two million All in taxes on small businesses. In this way all businesses will contribute to services obtained.

Treatment of freelancers like all businesses. A different approach would be unjust because taxes are determined based on the income generated.

\section{Reference}

[1] Albanian Institute of Statistics. Annual Bulletin. Available at www. instat. gov. al [Accessed on 17 April 2016]

[2] Beaver, G. \& Ross, C. 2000). Enterprise in recession: The role and context of strategy. International Journal of Entrepreneurship and Innovation, 1 (1), 23-31.

[3] Bumgardner, M. , Buehlmann, U. Schuler, A. , \& Crissey, J. 2011). Competitive actions of smaller firms in a declining market. Journal of Small Business Management, 49 (4), 578-598

[4] Fairlie, R. W. 2010). Kauffman Index of Entrepreneurial Activity, 1996-2009. Kansas City, MO: The Kauffman Foundation of Entrepreneurship.

[5] Generale Directory of Taxes-Albania. Annual Bulletin. Available at http://www. google. com/search?hl=en\&rls=com. microsoft:enUS\&rlz=117GPEA_en\&\&sa=X\&ei=4N4xTPz1FKCfOMKqqelB\&ved=0CBEQBSgA\&q=Burimi+\%3ABuletini+info rmativ+l+DPTTV-se+per+vitin+2008\&spell=1 [Accessed on 1 May 2016]

[6] Kushnir, K. , Mirmulstein, M. , Ramalho, R. , (2010). Micro small and medium enterprises around the world: How many are there, and what effects the count? Available at http://www. ifc. org/wps/wcm/connect/9ae1dd80495860d6a482b519583b6d16/MSME-Cl-AnalysisNote. pdf?MOD=AJPERES [Accessed on 20 May 2016]

[7] Penrose, E. 1995). The Theory of the Growth of Firms, 3rd ed. Oxford, NY: Oxford University Press.

[8] Shende, S. , (2002) Informal economy. The special tax regime for small and micro businesses: Design and implementation. Available at http://unpan1. un. org/intradoc/groups/public/documents/un/unpan006632. pdf [Accessed on 17 May 2016] 